\title{
Hypocholesterolemic Effect of Indian Medicinal Plants - A Review
}

\section{Munisankar Saravanan and Savarimuthu Ignacimuthu*}

Division of Ethnopharmacology, Entomology Research Institute, Loyola college, Chennai, Tamilnadu 600034 , India

\begin{abstract}
Indian medicinal plants have potent effects in treating diseases such as hypercholesterolemia. This review was performed on published Indian articles on hypocholesterolemic effect of Indian medicinal plants through literature search using Cochrane Library Database, Embase, Sci-finder, Pubmed with MeSH keywords and abstracts of Medicinal and Aromatic plants. All databases were searched from their respective inception until April 2011. About 15,620 papers were obtained using related titles and keywords through the electronic databases as well as various other sources. Therefore, 110 papers were finalized on native and naturalized Indian medicinal plants (24) belonging to various families and were then reviewed. Hypocholesterolemic effect of Indian medicinal plants was furnished with available animal models and clinical trials, which contribute to design new strategies to manage hypercholesterolemia.
\end{abstract}

Keywords: Hypercholesterolemia; Cardiovascular disease; Coronary heart disease; HMG-CoA reductase and bile acids

\section{Introduction}

Hypercholesterolemia is a major risk factor for the development and progression of atherosclerosis and related cardiovascular disease (CVD). Epidemiological, clinical, genetic and experimental studies indicate that high serum level of low density lipoprotein cholesterol (LDL-C) is associated with the cause [1]. Coronary heart disease (CHD) was first reported in European countries around 1980s, but now the prevalence has increased in the developing Asian countries due to changes in life style [2]. The Scandinavian Simvastatin Survival Study Group (4S), LIPID study and CARE study have clearly demonstrated that the reduction in cholesterol level reduces the risk of CHD in both normal and diabetic patients. Current projections suggest that by the year 2020, India will have the largest CVD burden in the world. One of the major initiating events in atherosclerosis is oxidative damage to the cholesterol component of the LDL, known as LDL oxidation, which forms atheromatous plague progressing to CVD. The World Health organization (WHO) estimates that $80 \%$ of the people of developing countries rely on traditional medicines, mostly plant-derived drugs, for their primary health needs. India is well known for its rich traditional systems of medicine, that is, Ayurveda, Siddha and Unani besides a vast reservoir of living traditions of ethnomedicine. Several modern drugs in use such as statins, fibrates, nicotinic acid and resins [3], lower blood cholesterol level, either by inhibiting endogenous synthesis and/or by lowering cholesterol absorption from the intestine [4]. Owing to their side effects, people are looking for safer alternatives, and the search for new drugs capable of reducing and regulating serum cholesterol level has gained interest resulting in numerous reports on significant activities of natural agents. In this review, the hypocholesterolemic property of Indian medicinal plants is enumerated.

\section{Methods}

Literatures pertaining to hypocholesterolemic potential of medicinal plants were obtained using Cochrane Library Database, Embase, Sci-finder, Pubmed with MeSH keywords and abstracts of Medicinal and Aromatic plants. All databases were searched from their respective inception until April 2011.

\section{Results}

About 15,620 papers were obtained using related titles and keywords through the electronic databases as well as various other sources. Therefore, 110 papers were finalized on native and naturalized Indian medicinal plants (24) belonging to various families and were then reviewed. This review shows the hypocholesterolemic effect of
Indian medicinal plants with available animal models and clinical trials. The findings are summarised below.

\section{Allium cepa L. (Family: Alliaceae)}

Hindi-Piyaj; English-Onion

Allium cepa is commonly cultivated throughout India; its bulb is used as food constituent. The therapeutic uses of onion such as antibiotic, antioxidant, antidiabetic, antiatherogenic, anticancer and fibrinolytic have been studied. Furthermore, juice of onion is also useful in treating jaundice, fever and chronic bronchitis (Wealth of India, 1985). Onion contains many sulfur containing active principles, which takes part in biological activities, mainly in the form of cysteine derivatives, namely, S-alkyl cysteine sulfoxides that decompose into a variety of thiosulfinates and polysulfides by the action of an enzyme allinase on extraction [5]. As allyl and related sulfoxides are inhibiting thiol group enzymes, alliums are to be used only in limited quantities [6].

\section{Allium sativum L. (Family: Alliaceae)}

\section{Hindi-Lasan; English-Garlic}

The botanical name Allium is derived from the Celtic word 'all', which means pungent. It is cultivated and commonly used as food ingredient. Garlic has been used as stimulant, carminative, antirheumatic and antihelmintic. The preventive role also extends against asthma, intestinal complaints, gout, diseases of lungs, high blood pressure and besides improves the immune system [7]. The essential oil fraction of garlic comprises $60 \%$ of diallyl disulphide (DADS) which showed hypocholesterolemic activity according to [8] Kamanna \& Chandrasekhara. In a study, Rai, Sharma, \& Tiwari [9] showed that sysnthesised DADS anologues showed activity equally effective as the statins and hence provide a new therapeutic approach for the treatment of CVD.

*Corresponding author: Savarimuthu Ignacimuthu, Division of Ethnopharmacology, Entomology Research Institute, Loyola college, Chennai, Tamilnadu 600 034, India, Tel: + 91442817 8348; Fax: + 91442817 5566; E-mail: entolc@hotmail.com

Received July 25, 2014; Accepted January 23, 2015; Published January 27, 2015

Citation: Saravanan M, Ignacimuthu S (2015) Hypocholesterolemic Effect of Indian Medicinal Plants - A Review. Med chem 5: 040-049. doi:10.4172/21610444.1000241

Copyright: (c) 2015 Saravanan M, et al. This is an open-access article distributed under the terms of the Creative Commons Attribution License, which permits unrestricted use, distribution, and reproduction in any medium, provided the original author and source are credited. 
Garlic has been investigated extensively for health benefits, resulting in more than 1000 publications over the last decade alone, and it is considered one of the best disease-preventive foods, based on its potent and varied effects. The major sulfur-containing compounds in intact garlic are $\gamma$-glutamyl-S-allyl-L-cysteines and S-allyl-L-cysteine sulfoxides (alliin). Both are abundant as sulfur compounds, and alliin is the primary odorless, sulfur-containing amino acid, a precursor of allicin. Alliinase is the key enzyme that facilitates the transformation of cysteine sulfoxides to thiosulfinates such as allicin. $\gamma$-Glutamyl-Sallyl-L-cysteines are converted into S-allylcysteines (SAC) through an enzymatic transformation with $\gamma$-glutamyltranspeptidase. Several clinical reports and meta-analyses have revealed the cholesterollowering effects of garlic supplementation in humans [10]. Warshafsky, Kamer, \& Sivak [11] have reported that neither garlic oil nor dehydrated garlic powder affects cholesterol levels. However, Amagase, Petesch, Matsuura, Kasuga, \& Itakura [12] clarified that allicin or allicin potential is not a correct marker for controlling the quality of garlic supplements. Allicin is thought to be a transient compound that rapidly decomposes into other sulphur-containing compounds such as diallyl disulfide (DADS), diallyl sulphide (DAS), diallyl trisulfide and sulfur dioxide and is not a genuine active compound of garlic. Freeman \& Kodera [13] also reported that no processed garlic preparations contain allicin, and it should not be a meaningful chemical evaluation for garlic products. One study concludes that the lack of effect is due to varied levels of allicin potential in the dehydrated garlic powder supplements used in the clinical studies [14].

SAC is the water-soluble organosulfur compound in garlic, which effectively reduces cholesterol synthesis and has been proven to be safe in toxicological studies. SAC is one of the active ingredients of aged garlic extract (AGE); a widely studied garlic preparation. Sliced raw garlic stored in $15-20 \%$ ethanol for 20 months is referred to as AGE. Many clinical, preclinical, and in vitro studies have shown that allicin-free garlic products, such as AGE, have clear and significant biological effects [15]. Based on the above evidences, water-soluble organosulfur compounds such as SAC should be considered reliable compliance markers for human clinical studies because they are among the active compounds of garlic, are stable, and have many biological effects in addition to their bioavailability. Thus, the standardization of garlic preparations using SAC as a chemical marker is scientifically reasonable and well justified [16].

\section{Semecarpus anacardium L. (Family: Anacardiaceae)}

\section{Hindi-Bhilawa; English-Marking nut}

Semicarpus anacardium is a deciduous tree found in the subHimalayan and tropical regions of India. Ripe fruit is regarded as stimulant, digestive, nervine and escharotic. It is used in the treatment of syphilis, rheumatism, piles, dyspepsia, epilepsy and other diseases of nervous system [7]. Ethanol extract of nut shell $(500 \mathrm{mg} / \mathrm{kg})$ decreased serum LDL-C and very low density lipoprotein cholesterol (VLDL-C) levels on 60 days of treatment in atherogenic male rabbits. Cholesterol mobilization from liver and prevention of deposition in peripheral tissues were observed and the inhibition of cholesterol absorption at intestine may be considered as the possible mode of action [17].

\section{Coriandrum sativum L. (Family: Apiaceae)}

\section{Hindi-Dhania; English-Coriander}

Coriandrum sativum is extensively cultivated in India for its seeds. Dried fruit is generally used for sore throat, flatulence, indigestion, vomiting and bilious complaints. Fresh plant is used in erythema and bleeding piles [7]; it is popularly known for its cooling and apetite increasing properties. C. sativum showed significant increase in hydroxy methyl glutaryl CoA (HMG-CoA) reductase and plasma lecithin cholesterol acyl transferase (LCAT) activity in hypercholesterolemic rats and enhanced degradation of cholesterol to faecal bile acids and neutral sterols. Concurrently, there was a decrease in VLDL-C and LDL-C levels with observed increase in high density lipoprotein cholesterol (HDL-C) level compared to control group [18].

\section{Commiphora mukul (Hook.ex Stocks) (Family: Burseraceae)}

\section{Hindi-Guggul; English-Indian bedellium}

Commiphora mukul grows abundantly in the arid and rocky areas of India. The Sushruta Samhita (600 B.C.), a well-known Ayurvedic medical text, describes the usefulness of the gum resin from the tree C. mukul in the treatment of a number of ailments, including obesity and disorders of lipid metabolism [19]. In Indian traditional system of medicine, the gum resin from C. mukul has been used in the treatments of rheumatism, nervous disorders, skin diseases, anaemia, cystitis, gonorrhoea and chronic bronchitis [7]. Inspired by a strong correlation between the modern concepts of atherosclerosis and obesity and descriptions in the Sushruta Samhita, Satyavati [20] studied the effect of gum guggul on the lipid levels of hyperlipidemic rabbits. Following her studies, a wide range of efforts have confirmed the hypolipidemic effect of gum guggul and lead to identification of the compounds such as $\mathrm{E}$ - and Z-guggulsterone the isomers of gum guggul as the active hypolipidemic agents.

Several mechanisms have been proposed for the effects of guggul. It may decrease hepatic steroid production, ultimately increasing the catabolism of plasma LDL-C. Alternatively, the proposed active components of guggul, guggulsterones $\mathrm{E}$ and $\mathrm{Z}$, may increase hepatic binding sites for LDL-C, thus increasing LDL-C clearance. Still another possibility is prevention of cholesterol synthesis in the liver by ketonic steroids. Guggulsterones $\mathrm{E}$ and $\mathrm{Z}$ are effective antagonists of the bile acids receptor, farnesoid $\mathrm{X}$ receptor (FXR), which is primarily expressed in the liver, kidney, and small intestine; it regulates the expression of genes involved in cholesterol/bile acids homeostasis, allowing more cholesterol catabolism and excretion from the body [21]. Studies of the efficacy of guggul for hypercholesterolemia have produced conflicting results and information currently available indicates that guggul may be effective for lowering total cholesterol and triglycerides in patients on a non-Western diet.

Since, hypercholesterolemia is a chronic disease, the longterm effects of guggul should be assessed and it may depend on dietary practices [22]. Szapary et al. [23] have reported that 8 weeks of treatment with guggulipid did not appear to improve levels of serum cholesterol among adults with hypercholesterolemia and in fact appeared to increase levels of LDL-C. Participants in their trial consumed on average $181 \mathrm{mg} /$ day of dietary cholesterol, which was less than a "typical American diet", and also less than the baseline dietary cholesterol $(212 \mathrm{mg} /$ day) from an Indian study of guggulipid that reported positive results [24] guggulsterones may be effective only in individuals who have an excessive dietary intake of cholesterol.

\section{Terminalia arjuna Weight \& Arn (DC.) (Family: Combretaceae)}

\section{Hindi-Arjun; English-Arjuna}

Terminalia arjuna is seen in lower Himalayas, central and southern parts of India. The thick, white-to-pinkish-gray bark has been used in India's native Ayurvedic medicine for over three centuries, primarily as a cardiac tonic. Clinical evaluation of this botanical medicine indicates that it can be of benefit in the treatment of CAD, heart failure, and 
possibly hypercholesterolemia [25]. The bark is astringent, tonic and also used to treat diarrhea, dysentry and bilious infections. It is further recommended for kapa, pitta and vayu [7]. The main constituents of the bark powder include glycosides (Arjunine, Arjunetin, Arjunoside I, Arjunoside II, Triterpene-o-glycoside). Ethanolic extract of bark of T. arjuna (100 and $500 \mathrm{mg} / \mathrm{kg}$ ) treated to atherogenic albino rabbits reduced TC after 60 days. Both the dosage forms were observed effective in decreasing TC and LDL-C levels, whereas the TC: HDL ratio was influenced by the higher dose [26]. In a randomized placebo-controlled trial, T. arjuna tree bark powder (500 mg) significantly decreased TC level in 105 successive CAD patients [27]. The hypolipidemic action of T. arjuna coupled with the enhancement of prostaglandin E2 (PGE2) like activity, anti-arrhythmic, anti-hyperrtensive and HDL-C raising properties make it an imminently cardio-protective product for the overall management of CAD [28].

\section{Emblica officinalis L. (Family: Euphorbiaceae)}

\section{Hindi-Amla; English-Indian gooseberry}

Emblica officinalis is a deciduous tree cultivated in hill slopes and plains in the Deccan region, coastal districts and northern parts of India. Leaf, bark and fruit have potential efficacy against diseases such as inflammation, cancer, age-related renal disease, diabetes, anemia, jaundice, diarrhea and peptic ulcer [29]. Amla extract given (10 and 20 $\mathrm{mg} / \mathrm{kg}$ ) to hypercholesterolemic rabbits had the ability to prevent LDL oxidation; besides it decreased synthesis of cholesterol and enhanced reverse cholesterol transport by elevating HDL-C level [30].

\section{Phyllanthus niruri L. (Family: Euphorbiaceae)}

\section{Hindi-Bhuiamla; English-Niruri}

Phyllanthus niruri is a small herb distributed commonly in central and southern parts of India. This plant has medicinal properties for dysentry, influenza, diabetes, jaundice, genito-urinary infections and viral infections [7]. Supplementing $P$. niruri plant $(100 \mathrm{mg} / \mathrm{kg})$ with cholesterol $(25 \mathrm{mg} / \mathrm{kg})$ to rats for a period of 30 days, lowered lipids, VLDL-C and LDL-C levels [31]. The anti-hypercholesterolemic effect of this plant was assessed to be mediated through the inhibition of hepatic cholesterol biosynthesis, increased excretion of bile acids and enhanced plasma LCAT activity.

\section{Cicer arietinum L. (Family: Fabaceae)}

\section{Hindi-Chana dal; English-Bengal gram}

Cicer arietinum is cultivated in southern India; it is given for skin and lipid disorders, indigestion, vomiting, diarrhoea, dysmenorrhoea and for fever [7]. The increase in membrane cholesterol of erythrocytes because of hypercholesterolemic diet leads to osmotic fragility, which was reflected in packed cell volume and erythrocyte count. A direct relation in decrease of allosteric enzyme $\left(\mathrm{Na}^{+}-\mathrm{K}^{+}\right)$-ATPase (membrane bound enzyme) activity was noticed. This condition was reversed by treating with dietary fibre of bengal gram [32]. Conflicting reports have appeared concerning the beneficial effect of legume fibre on cholesterogenesis [33,34]. One of the difficulties in assessing the physiological role of fibres relates to the fact that their composition may vary widely. However, it is now fairly well established that dietary fibre is composed of a hydrophilic component and a more hydrophobic or ionic component that have been ascribed to the ability to hydrate or to behave as a weak ion exchanger, which can sequester bile acids and other sterols by preventing reabsorption, thereby decreasing body cholesterol stores [35].

Bengal gram fibre exhibited maximum hypocholesterolemic and hypolipidemic effect as the water absorption and holding capacity of the fibre was useful in assessing their hypocholesterolemic effect with bile acids [36]. Menon and Kurup [37] have proposed that the fibre in bengal gram especially pectin may lower cholesterol levels by absorbing bile acids. The consequent loss of bile acids by faecal excretion is then offset by an increase in hepatic conversion of cholesterol into bile acids. The protective role appears to be rendered by the hydroxyl and carboxyl groups of uronic acid present in the pectin molecule. Bengal gram consists of isoflavones Biocharin A and Formononetin in high amounts, which were estrogen-like compounds and most probably the active compounds responsible for lowering serum cholesterol level [38].

\section{Cyamopsis tetragonoloba (L.) Taub. (Family: Fabaceae)}

\section{Hindi-Guar; English-Cluster bean}

Cyamopsis tetragonoloba is a vegetable cultivated throughout India. It is rich in polysaccharide and dietary fibre consumed frequently. The pods are sweet, cooling, laxative, digestive and appetizer. It is useful in treating constipation, dyspepsia, anorexia, agalactia, nyctolopia and vitiated conditions of pitta [39]. Aqueous, alcoholic and petroleum ether extracts and residual seed meal of guar were fed to hypercholesterolemic albino rats for 3 months. Among them, petroleum ether extract exerted a significant hypocholesterolemic effect [40]. Cluster bean powder $(0.5 \%$ and $2.5 \%)$ showed reduction in serum cholesterol level in 7 weeks when administered to albino rats [41]. Guar gum (15 g) given with normal diet to overweight adults for 6 weeks produced a significant reduction in plasma LDL-C and TC: HDL-C ratio [42].

\section{Glycine max (L.) Merr. (Family: Fabaceae)}

\section{Hindi-Bhat; English-Soya bean}

Glycine max is an important global crop; it is native to East Asia and provides oil and protein [43]. Fibre of soy bean showed maximum plasma cholesterol lowering effect in hypercholesterolemic male albino rats compared with fibres of cereals and pulses isolated from the seed coat when administered for 4 weeks [44]. Caroll and Potter [45,46] reviewed various hypotheses on the effects of components such as isoflavones, fibre and saponins in soy beans which include, interruption of the intetstinal absorption of bile acids and dietary cholesterol, direct effects on the hepatic metabolism of cholesterol, alteration of the concentration of the hormone involved in cholesterol metabolism. In vitro bile acids binding capacity was evident with legume fibres than with cereal fibres and the presence of soy phytoestrogens (isoflavones: genistein and daidzein) in soya was suggested as the agents responsible for reducing serum cholesterol level.

\section{Glycyrrhiza glabra L. (Family: Fabaceae)}

\section{Hindi-Muleti; English-Licorice}

Glycyrrhiza glabra is found in India; its root decoction is given for sore-throat, asthma, dysuria and used as tonic and laxative [7]. When the root powder of G. glabra (5\% and 10\%) was administered to hypercholesterolemic male albino rats for 4 weeks, it decreased plasma and liver cholesterol levels, whereas the HMG-CoA reductase activity and HDL-C levels were significantly increased [47] and in another study [48], the effect of roots of G. glabra has been seen (5\%, given for 4 weeks) to reduce plasma and hepatic lipid profiles and increased faecal excretion of cholesterol, neutral sterol, and bile acids in hypercholesterolemic rats.

\section{Trigonella foenum-graecum L. (Family: Fabaceae)}

Hindi-Methi; English-Fenugreek 
Trigonella foenum-graecum is cultivated in many parts of India. It is an aromatic herb rich in fibre; hence the seeds and green leafy parts are used in cooking. Seeds are given to treat flatulence, diarrhea, dyspepsia, chronic cough, gout and diabetes [7]. Several more recent animal and human clinical trials have confirmed the therapeutic application of fenugreek seeds. Combined with its long history of safe use, it is no surprise that fenugreek is gaining a reputation as a promising herbal supplement for optimal health. The seed contain an excellent source of mucilaginous fibre mainly composed of galactomannans. Even more impressive is the content of saponins in the seeds that can improve bile acids and neutral sterols excretion as well as faecal weight [49]. Fenugreek powder (15\%, 30\% and 60\%) mixed with hypercholesterolemia inducing diet and fed to rats for 4 weeks showed decrease in serum LDL-C and VLDL-C levels. In another study, fenugreek seed powder $(5 \%, 10 \%$ and $15 \%)$ showed antilithogenic effect in mice. Cholesterol gallstones (CGS) were induced by providing lithogenic diet $(0.5 \%$ cholesterol) for 10 weeks. Fenugreek seed offers health-beneficial antilithogenic potential by virtue of its favourable influence on cholesterol metabolism by decreasing serum, hepatic and biliary cholesterol levels [50].

\section{Vigna aconitifolia (Jacq.) Marechal (Family: Fabaceae)}

\section{Hindi-Moth; English-Mat bean}

Vigna aconitifolia, a perennial or annual herb, is found throughout India. The tender pods are used as vegetable and the plant is used as fodder for live stock [51]. The hypocholesterolemic effect of moth bean protein was compared with pigeon pea and casein in albino rats. After 45 days of treatment, the moth bean protein significantly lowered total and LDL-C levels and markedly increased HDL-C level [52].

\section{Vigna mungo (L.) Hepper (Family: Fabaceae)}

\section{Hindi-Urad dal; English-Black gram}

Vigna mungo has been in cultivation since ancient times and it is one of the most highly prized pulses of India. Ground into flour or paste, it is extensively used in culinary preparations and green pod is consumed as vegetable. It is given to patients with enlarged spleen and liver, for fistula and to relieve heat and burning sensation of eyes [7]. The fibre-rich polysaccharide from black gram decreased cholesterol level in serum, liver and aorta of rats fed with normal and high fat cholesterol diet [37].

Neutral detergent fibre (NDF) residue of black gram showed higher enzyme activity (HMG-CoA reductase: mevalonate ratio) in male albino rats; hence, the rate of degradation of cholesterol in liver was greater than the rate of cholesterogenesis resulting in higher concentration of bile acids production. A decrease in bile acids return through enterohepatic circulation was observed as a result of binding of NDF to bile acids in the intestine [53]. But, hydroalcoholic extract of the seeds of $V$. mungo showed decreased HMG-CoA reductase activity, increased biliary excretion, and decreased absorption of dietary cholesterol in poloxamer 407-induced hyperlipidemic rats [54].

\section{Vigna unguiculata (L.) Walp. (Family: Fabaceae)}

\section{Hindi-Lobhia; English-Cowpea}

Vigna unguiculata is a sub-erect, bushy annual found in warmer parts of India [50]. It is given for anorexia, constipation, helminthiasis, agalactia, jaundice and general debility [55]. The green pods and leaves are eaten as food. It is a good fodder for milk cows. Studies were carried out in atherogenic albino rats treated with whole, defatted and hexane extracts of cowpea; among them hexane-extract was effective in lowering the serum and liver cholesterol levels and increased bile acids excretion in faeces. The presence of neutral lipids in the extract possibly exhibited hypocholesterolemic effect [56].

\section{Ocimum sanctum L. (Family: Labiateae)}

\section{Hindi-Tulsi; English-Holy basil}

Ocimum sanctum is a widely grown sacred plant of India. Each part of the plant has a medicinal value; especially the juice of the plant is diaphoretic, expectorant, relieves headache and is used for skin disorders, malaria, cholera and chronic fever [7]. O. sanctum seed oil $(0.8 \mathrm{~g} / \mathrm{kg})$ showed decrease in TC, triglycerides, LDL-C and VLDL-C levels from second to fifth week in male albino rabbits; decrease in lipid peroxidation and improvement in antioxidant status were observed [57]. Geetha \& Vasudevan [58] showed inhibition of erythrocyte lipid peroxidation and protection of liver and aortic tissue of hypercholesterolemia-induced male albino rabbits by feeding aqueous extracts of Ocimum.

\section{Linum usitatissimum L. (Family: Linaceae)}

\section{Hindi-Alsi; English-Linseed}

Linum usitatissimum is grown at the eastern Mediterranean region of India. It is given for cold, cough, bronchial infections, cystitis, gonorrhea, diarrhea and dysentry [7]. Prasad [59] reported that rabbits receiving secoisolariciresinol digluside, the major lignan found in flaxseed, had reduced TC and LDL-C concentrations. Lignans have also been shown to modulate activities of 7-hydroxylase and acyl CoA cholesterol transferase, two of the key enzymes involved in cholesterol metabolism [60]. Flaxseed oil ( $1 \mathrm{~g} / \mathrm{kg} \mathrm{bw})$, when administered to male albino rats along with high fat diet (HFD) for 60 days, however, decreased LDL-C, VLDL-C, TC: HDL-C and LDL-C: HDL-C ratios. Flax seed oil contained 51\%-55\% alpha-linolenic acid (18:3 n-3 fatty acid) that resulted in higher cholesterol secretion into bile leading to a depletion of intrahepatic pool of cholesterol [61].

\section{Moringa oleifera Lam. (Family: Moringaceae)}

\section{Hindi-Sajna; English-Drumstick}

Moringa oleifera is a very well-known botanical used in traditional medicine in India; generally all parts of the tree are eaten. Juice of the root is used for asthma, gout, lumbago, rheumatism, epilepsy and hysteria. Leaves are given for scurvy and applied topically for dog bites [7]. The crude extract of leaves $(1 \mathrm{mg} / \mathrm{g})$ given with high fat diet for a period of 30 days led to decrease in cholesterol levels in serum, liver and kidney. The presence of phytosterol and $\beta$-sitosterol in the leaf is presumably the bioactive component with cholesterol lowering property [62]. The fruits of $M$. oleifera $(200 \mathrm{mg} / \mathrm{kg})$ given along with standard laboratory diet and hypercholesterolaemic diet to rabbits for 120 days were found to lower the serum cholesterol, phospholipid, triglycerides, VLDL-C, LDL-C and atherogenic index, but were found to increase the HDL-C as compared to the corresponding control groups [63]

\section{Sesamum indicum L. (Family: Pedaliaceae)}

\section{Hindi-Til; English-Gingelly seed}

Sesamum indicum is extensively cultivated in the warmer regions of India mainly for its edible seeds and oil. The seed is beneficial for amenorrhoea and dysmenorrhoea and oil is recommended for psoriasis, prurigo, leucoderma and in promoting hair growth [7]. Sesame seed globulin fraction has low lysine: argenine ratio; when this was administered to male albino rats in an experimental period of 90 days, it decreased LDL-C, VLDL-C and increased the activity of plasma LCAT; this enzyme transports cholesterol from tissues to liver for 
catabolism [64]. The hypocholesterolemic effect of sesame seed powder administered (5\% and $10 \%)$ to hypercholesterolemic male albino rats showed decline in plasma LDL-C level, increase in hepatic HMGCoA reductase activity and enhanced faecal bile acids and cholesterol excretion. The hypocholesterolemic effect appeared to be due to its fibre, sterol, polyphenol and flavonoid contents [65].

\section{Oryza sativa L. (Family: Poaceae)}

\section{Hindi-Chawalya dhan; English-Rice}

Oryza sativa, an annual or perennial grass, is distributed in the tropical and sub-tropical regions of India. It is the staple diet consumed principally. Rice bran oil (RBO) is extracted from the pericarp and germ of the rice. The oil is reported to prevent cancer in the liver of rats [66]. RBO typically contains $20 \%$ saturated fatty acids and approximately equal amounts of oleic and linoleic fatty acids [67]. Attention has begun to focus on the components of RBO, which is richer in triterpene alcohols, tocopherols, sterols, tocotrienols, and oryzanol; the most notable compound is $\gamma$-oryzanol, a ferulate ester of triterpene alcohols [68]. The phytosterols, campesterol and $\beta$-sitosterol are found at relatively high amounts in RBO. The $\beta$-sitosterol structure is more similar to that of cholesterol and it may be more effective in inhibiting cholesterol absorption in the small intestine. In tocotrienols, the major components are the $\beta$ - and $\gamma$-tocotrienols; it is postulated that $\gamma$-tocotrienols lower cholesterol through the inhibition of HMG$\mathrm{CoA}$ reductase, the rate-limiting enzyme in endogenous cholesterol synthesis [69].

Most, Tulley, Morales, \& Lefevre [70] showed that RBO and not defatted rice bran, exhibited hypocholesterolemic effect in two wellcontrolled studies in moderately hypercholesterolemic men and women confirming the presence of unsaponifiable substances in RBO. The unsaponifiable substances present in the ether extract of RBO also prevented the increase in mean serum cholesterol level in hypercholesterolemic albino rats [71].

\section{Capsicum annuum L. (Family: Solanaceae)}

\section{Hindi-Lalmirch; English-Chilli}

Capsicum annuum is one of the most important commercial spice crop grown in tropical and sub-tropical regions of India. With cinchona it is useful in atonic gout, advanced stages of rheumatism and with asafoetida it is used in treating cholera [7]. Capsicum oleoresin $(75 \mathrm{mg} / \mathrm{kg}$ bw/day) showed reducing effect in serum cholesterol and triglycerides levels in hypercholesterolemic gerbils [72]. The red pepper or its active principle capsaicin showed significant reduction in rise of liver cholesterol and brought enhanced faecal excretion of both free cholesterol and bile acids in female albino rats. The hypocholesterolemic action of capsaicin is likely to be responsible for the presence of common vanillyl moiety [73].

\section{Withania somnifera (L.) Dunal. (Family: Solanaceae)}

\section{Hindi-Ashvagandha; English-Winter cherry}

Withania somnifera grows prolifically in India and is commercially cultivated in Madhya Pradesh. Fruits and seeds are used as diuretic; root is used for constipation, rheumatism, nervous exhaustion and spermatorrhoea [7]. Studies have reported that this plant possesses antiinflammatory, antitumor, antistress, antioxidant, immunomodulatory and rejuvenating properties [74]. W. somnifera showed reduction in cholesterol level of serum in rats fed with high calorie and fat diet [75]. The root powder of $W$. somnifera ( 0.75 and $1.5 \mathrm{gm} / \mathrm{rat} /$ day) when administered to hypercholesterolemic rats showed decrease in serum cholesterol level; on the other hand, significant increase in plasma HDL-C level and HMG-CoA reductase activity were noticed [76].

\section{Curcuma longa L. (Family: Zingiberaceae)}

\section{Hindi-Haldi; English-Turmeric}

Curcuma longa is a rhizomatous perennial herb, a native of East India. The ancient practitioners in India used turmeric as stomachic, tonic and carminative, as antibacterial, antiseptic and as antihelminthic. It is applied as paste to bruises, wounds and conjunctivitis [7]. Rhizome has been reported to contain the important colouring matter curcumin, which belongs to the dicinimolymethane group. It has also been reported that sodium curcuminate isolated from C. longa is an active cholerectic which causes an increase in total excretion of bile salts, bilirubin and cholesterol [77].

The fluidity of the erythrocyte membrane is determined by cholesterol content, fatty acid composition of the membrane phospholipids and the protein matrix. In a hypercholesterolemic situation, the concomitantly higher cholesterol to phospholipids ratio in the blood plasma will have a direct influence on cholesterol transfer from plasma to erythrocytes, resulting in the enrichment of cholesterol in the erythrocyte membrane [78]. The dietary spice principle curcumin (0.2\%) given for 8 weeks showed its ability in reversing the deformity and fragility and normalizing the fluidity in the erythrocytes [79]. The hypocholesterolemic activity of curcumin was examined in human hepatoma cell line HepG2. Curcumin treatment caused increase in LDL-receptor mRNA and moderate increase in expression of the sterol regulatory enzyme binding protein (SREBP) genes. But mRNAs of the peroxisome proliferator activated receptor- $\alpha$ (PPAR- $\alpha$ ) target genes $\mathrm{CD} 36 /$ fatty acid translocase and fatty acid binding protein 1 were down regulated. These changes in gene expression are consistent with the proposed hypocholesterolemic effect of curcumin [80].

\section{Discussion}

Cholesterol is a vital constituent of cell membrane and the precursor of steroid hormones and bile acids. In a healthy organism, an intricate balance is maintained between the biosynthesis, utilization and transport of cholesterol, keeping its harmful deposition to a minimum. The positive association of raised total serum cholesterol levels and of lipoproteins in relation to incidence of atherosclerosis and CHD is well established $[81,82]$. The protective effect of HDL against atherosclerosis and CHD has also been well documented [83]. The Multiple Risk Factor Intervention Trial (MRFIT) and the Framingham Heart Study have reported an increase in CAD risk by $3 \%$ in men and $34 \%$ in women with every milligram decrease in HDL level [84]. Furthermore, cholesterol homeostasis is ensured by the coordinated interaction of LDL receptor expression, HMG-CoA reductase and LCAT activity.

Spices form an important class of food adjuncts and are known to exhibit a wide variety of physiological and pharmacological properties; they have been documented to have significant hypolipidaemic influence in a variety of experimental animal systems and are found to be efficacious in human studies too [85]. The structural integrity of RBC was affected by increased osmotic fragility in rats maintained on cholesterol-enriched diet. Spices would beneficially prevent the alteration in erythrocyte membrane lipids and would offer beneficial protective influence on the integrity of erythrocyte membranes.

Catabolism of cholesterol to bile acids is quantitatively the most important pathway of elimination of cholesterol from the body. It is said 
Citation: Saravanan M, Ignacimuthu S (2015) Hypocholesterolemic Effect of Indian Medicinal Plants - A Review. Med chem 5: 040-049. doi:10.4172/2161-0444.1000241

that changes in the rate of synthesis of bile acids are nearly paralleled by corresponding changes in the rate of cholesterol biosynthesis in the liver [86]. Pulses form an important component of the Indian diet and have been reported to lower the cholesterol levels because of their proteins, carbohydrates and/or fibre content [36]. Dietary fibres appear to interfere with increased excretion of cholesterol and faecal bile acids resulting in depletion of hepatic cholesterol pools and alteration in lipoprotein metabolism [87]. It is known that phytosterols have a greater affinity for micelles than cholesterol because of their greater hydrophobicity, thereby reducing intestinal cholesterol absorption, and consequently reduce hepatic and plasma cholesterol concentrations [88]. Saponins are also capable of precipitating cholesterol from micelles and interfering with enterohepatic circulation of bile acids making it unavailable for intestinal absorption and hence reduce plasma cholesterol levels [89]. The medicinal plants dealt in this review have shown profound effects in the management of hypercholesterolemia in both animal models (Table 1) and clinical trials (Table 2) thus paving way for better therapeutic agents for atherosclerosis and CVD [90-140].

\begin{tabular}{|c|c|c|c|c|}
\hline Plant/ Family & Animal Model & Phytoconstituents & Activity & References \\
\hline \multirow[t]{5}{*}{ Allium cepa/ Alliaceae } & white albino rabbits & Onion & Decreased erythrocytes crenation & Vatsala \& Singh, 1981 \\
\hline & white albino rabbits & Onion & Decreased erythrocytes crenation & Vatsala \& Singh, 1980 \\
\hline & Male albino rats & Onion juice & Hypocholesterolemic & Sharma, Chowdhury, \& Sharma, 1975a \\
\hline & Male albino rabbits & Onion juice & Hypocholesterolemic & Sharma, Chowdhury, \& Sharma, 1975b \\
\hline & Male albino rats & Fibre & Hypocholesterolemic & Vadhera, Punia, \& Soni, 1995 \\
\hline \multirow[t]{8}{*}{$\begin{array}{l}\text { Allium sativum/ } \\
\text { Alliaceae }\end{array}$} & Goats & Garlic capsules & Hypocholesterolemic & Kaul \& Prasad, 1990 \\
\hline & Male rabbits & Garlic & Anti-atherosclerotic & Mirhadi, Singh, \& Gupta, 1991 \\
\hline & Female albino rats & Garlic powder & Hypocholesterolemic & Kamanna \& Chandrasekhara, 1982 \\
\hline & Male albino rabbits & Garlic oil & Anti-atherosclerotic & Jain \& Konar, 1978 \\
\hline & Male albino rats & Garlic protein & $\begin{array}{l}\text { Anti-atherogenic and } \\
\text { anti-peroxidative }\end{array}$ & Rajasree, Rajmohan, \& Augusti, 2009 \\
\hline & Wistar rats & Diallyldisulfide & Hypocholesterolemic & Rai, Sharma, \& Tiwari, 2009 \\
\hline & Dogs of either sex & Garlic pearls & Hypocholesterolemic & Das, Pramanik, Mitra, \& Mukherjee, 1982 \\
\hline & Male albino rabbits & Garlic & $\begin{array}{l}\text { Hypercholesterolemic effect during } \\
\text { treatment }\end{array}$ & Gupta, Khetrapal, \& Ghai, 1987 \\
\hline \multirow[t]{5}{*}{$\begin{array}{l}\text { Commiphora mukul/ } \\
\text { Burseraceae }\end{array}$} & Male albino rabbits & Alcoholic extract and steroid & $\begin{array}{l}\text { Marked hypocholesterolemic effect by } \\
\text { steroid }\end{array}$ & Nityanand \& Kapoor, 1971 \\
\hline & Indian domestic pigs & Resin & Hypocholesterolemic & Khanna, Agarwal, Gupta, \& Arora, 1969 \\
\hline & Male albino rabbits & Oleoresin fraction & Hypocholesterolemic & Satyavati, Dwarakanath, \& Tripathi, 1969 \\
\hline & $\begin{array}{l}\text { Male white leg-horn } \\
\text { chicks }\end{array}$ & $\begin{array}{l}\text { Steroid, alcoholic extract and } \\
\text { terpenoid }\end{array}$ & $\begin{array}{l}\text { Marked hypocholesterolemic effect by } \\
\text { steroid }\end{array}$ & Malhotra, Agarwal, Mehta, \& Prasad, 1970 \\
\hline & Normal male rats & Steroid & Hypocholesterolemic & Nityanand \& Kapoor, 1973 \\
\hline $\begin{array}{l}\text { Emblica officinalis/ } \\
\text { Euphorbiaceae }\end{array}$ & Albino rabbits & Amla & Hypocholesterolemic & Thakur, 1985 \\
\hline \multirow[t]{6}{*}{$\begin{array}{l}\text { Cicer Arietinum/ } \\
\text { Fabaceae }\end{array}$} & Albino rats & Fibre of different pulses & $\begin{array}{l}\text { Marked hypocholesterolemic effect by } \\
\text { bengal gram }\end{array}$ & Soni, George, \& Singh, 1982 \\
\hline & Albino rats & Lipid extract & Hypocholesterolemic & Mathur, Sharma, \& Singhal, 1964a \\
\hline & Male albino rabbits & Seed coat & Hypocholesterolemic & Mand, Soni, Gupta, Vadhera, \& Singh, 1992 \\
\hline & Male albino rats & Whole, defatted and lipid extract & Hypocholesterolemic & Mathur, Singhal, \& Sharma, 1964b \\
\hline & Rabbits & Bengal gram and Biochanin A & Hypocholesterolemic & Gopalan, Gracias, \& Madhavan, 1991 \\
\hline & Male albino rats & Tannin, phytic acid and pectin & $\begin{array}{l}\text { Marked hypocholesterolemic effect } \\
\text { by pectin }\end{array}$ & Sharma, 1984a \\
\hline $\begin{array}{l}\text { Glycine max/ } \\
\text { Fabaceae }\end{array}$ & Albino rabbits & Defatted soya protein & Anti-atherosclerotic & Thakur \& Ali, 1982 \\
\hline $\begin{array}{l}\text { Trigonella foenum- } \\
\text { graecum/ Fabaceae }\end{array}$ & Rabbits & Galactomannan & $\begin{array}{l}\text { Hypocholesterolemic and anti- } \\
\text { atherogenic effect }\end{array}$ & Boban, Nambisan, \& Sudhakaran, 2009 \\
\hline \multirow[t]{3}{*}{$\begin{array}{l}\text { Vigna mungo/ } \\
\text { Fabaceae }\end{array}$} & Male albino rats & Protein & Anti-atherosclerotic & $\begin{array}{l}\text { Jayakumari, Nampoothiri, Nambisan, \& } \\
\text { Kurup, } 1978\end{array}$ \\
\hline & Male albino rats & Neutral detergent fibre & Anti-atherosclerotic & Jayakumari \& Kurup, 1979 \\
\hline & Male albino rats & Neutral detergent fibre & Hypocholesterolemic & Thomas, Leelamma, \& Kurup, 1986 \\
\hline $\begin{array}{l}\text { Capsicum annuum/ } \\
\text { Solanaceae }\end{array}$ & Female wistar rats & Capsaicin & Anti-peroxidative & Kempaiah, Manjunatha, \& Srinivasan, 2005 \\
\hline $\begin{array}{l}\text { Withania somniferal } \\
\text { Solanaceae }\end{array}$ & Wistar rats & Aqueous extract of fruits & Hypocholesterolemic & $\begin{array}{l}\text { Hemalatha, Wahi, Singh, \& Chansouria, } \\
2006\end{array}$ \\
\hline \multirow[t]{7}{*}{$\begin{array}{l}\text { Curcuma longa/ } \\
\text { Zingiberaceae }\end{array}$} & Wistar rats & Curcumin & Hypocholesterolemic & Manjunatha \& Srinivasan, 2007 \\
\hline & Male albino mice & Curcumin & Hypocholesterolemic & $\begin{array}{l}\text { Soudamini, Unnikrishnan, Soni, \& Kuttan, } \\
1992\end{array}$ \\
\hline & Diabetic male albino rats & Curcumin & Hypocholesterolemic & Suresh babu \& Srinivasan, 1995 \\
\hline & Female albino rats & Ethanol extract & Hypocholesterolemic & $\begin{array}{l}\text { Subba Rao, Chandra Sekhara, } \\
\text { Satyanarayana, \& Srinivasan, } 1970\end{array}$ \\
\hline & Albino mice & Turmeric & Hypocholesterolemic & Godkar, Narayanan, \& Bhide, 1996 \\
\hline & Wistar rats & Curcumin & Decreased erythrocytes crenation & Kempaiah \& Srinivasan, 2002 \\
\hline & Diabetic rats & Curcumin & Hypocholesterolemic & Babu \& Srinivasan, 1997 \\
\hline
\end{tabular}

Table 1: Animal studies on hypocholesterolemic effect of Indian medicinal plants. 
Citation: Saravanan M, Ignacimuthu S (2015) Hypocholesterolemic Effect of Indian Medicinal Plants - A Review. Med chem 5: 040-049. doi:10.4172/2161-0444.1000241

\begin{tabular}{|c|c|c|c|c|}
\hline Plant/ Family & Study model & Phytoconstituents & Activity & References \\
\hline Allium cepa/ Alliaceae & 10 healthy subjects & Onion extract & Decreased erythrocytes crenation & Singh \& Kanakaraj 1985 \\
\hline \multirow[t]{6}{*}{ Allium sativum/ Alliaceae } & $\begin{array}{l}15 \text { hypercholesterolemic } \\
\text { patients of either sex }\end{array}$ & Aqueous extract & Hypocholesterolemic & Augusti, 1977 \\
\hline & 25 healthy males & Garlic & Hypocholesterolemic & $\begin{array}{l}\text { Bhushan, Sharma, Singh, Agrawal, } \\
\text { Indrayan, \& Seth, } 1979\end{array}$ \\
\hline & 10 healthy volunteers & Garlic & Hypocholesterolemic & Sharma, Sharma, Dwivedi, \& Sharma, 1976 \\
\hline & 50 normal volunteers & Garlic & $\begin{array}{l}\text { Hypocholesterolemic and anti- } \\
\text { thrombotic }\end{array}$ & Gadkari \& Joshi, 1991 \\
\hline & $\begin{array}{l}32 \text { hypercholesterolemic } \\
\text { patients of either sex }\end{array}$ & Garlic pearls & Hypocholesterolemic & $\begin{array}{l}\text { Jeyaraj, Shivaji, Jeyaraj, \& Vengatesan, } \\
2005\end{array}$ \\
\hline & $\begin{array}{l}20 \text { normotensive and } 20 \\
\text { hypertensive patients }\end{array}$ & Garlic pearls & Anti-hypertensive & Dhawan \& Jain, 2004 \\
\hline \multirow[t]{2}{*}{$\begin{array}{l}\text { Commiphora mukul/ } \\
\text { Burseraceae }\end{array}$} & $\begin{array}{l}120 \text { hypercholesterolemic } \\
\text { patients }\end{array}$ & $\begin{array}{l}\text { Gum and petroleum ether } \\
\text { fraction }\end{array}$ & Hypocholesterolemic & $\begin{array}{l}\text { Kuppurajan, Rajagopalan, Koteswara Rao, } \\
\text { \& Sitaraman, } 1978\end{array}$ \\
\hline & 205 patients & Guggulipid & Hypolipidemic & Nityanand, Srivastava, \& Asthana, 1989 \\
\hline \multirow[t]{2}{*}{$\begin{array}{l}\text { Emblica officinalis/ } \\
\text { Euphorbiaceae }\end{array}$} & $\begin{array}{l}15 \text { normal and } 20 \\
\text { hypercholesterolemic men }\end{array}$ & Amla & Hypocholesterolemic & Jacob, Pandey, Kapoor, \& Saroja, 1988 \\
\hline & 30 patients & Amlamax capsules & Hypocholesterolemic & Antony, Merina, \& Sheeba, 2008 \\
\hline
\end{tabular}

Table 2: Clinical studies on hypocholesterolemic effect of Indian medicinal plants.

\section{Conclusion}

Herbs have been used in medical treatment since the beginning of civilization and have become a mainstay of human pharmacotherapy. Based on this, many works were carried out in evaluating the hypocholesterolemic effect of plants and from the reports on their potential effectiveness; it is assumed that the botanicals have a major role to play in the management of hypercholesterolemia. Medicinal plants reviewed here have shown great cholesterol reducing property in normal as well as high fat/cholesterol treated animals thus showing protective role in the progression of atherosclerosis. More concentration in evaluating the beneficial effects of medicinal plants certainly will help to utilize the Indian biodiversity and traditional knowledge for prospecting novel compounds as pharmacologically effective products to manage hypercholesterolemia.

\section{Acknowledgement}

We are grateful to Entomology Research Institute, Loyola College, Chennai, India for financial assistance.

\section{References}

1. Ballantyne CM (1998) Clinical trial endpoints: angiograms, events, and plaque instability. Am J Cardiol 82: 5M-11M.

2. Durrington PN (1999) Diabetic dyslipidaemia. Baillieres Best Pract Res Clin Endocrinol Metab 13: 265-278.

3. Satoskar RS, Bhandarkar SD, Ainapure SS (2003) Hypolipidemic drugs. In Pharmacology and Pharmacotherapeutics, 18th ed. Popular Prakashan, Mumbai, India 567-575.

4. Sedaghat A, Samuel P, Crouse JR, Ahrens EH Jr (1975) Effects of neomycin on absorption, synthesis, and/or flux of cholesterol in man. J Clin Invest 55: $12-21$

5. Brewster JL, Rabinowitch HD (1990) Onions and allied crops, Vol. III, CRC Press, Inc Boca, sFlorida, 18\&83.

6. Augusti KT (1996) Therapeutic values of onion (Allium cepa L.) and garlic (Allium sativum L.). Indian J Exp Biol 34: 634-640.

7. Nadkarni KM, Nadkarni AK (1954) Indian materia medica, Voll, (3rd edn.) Popular Prakashan, Mumbai, India.

8. Kamanna VS, Chandrasekhara N (1984) Hypocholesteremic activity of differen fractions of garlic. Indian J Med Res 79: 580-583.

9. Rai SK, Sharma M, Tiwari M (2008) Synthesis, DNA binding, and cytotoxic evaluation of new analogs of diallyldisulfide, an active principle of garlic. Bioorg Med Chem 16: 7302-7310.

10. Silagy CA, Neil HA (1994) A meta-analysis of the effect of garlic on blood pressure. J Hypertens 12: 463-468.
11. Warshafsky S, Kamer RS, Sivak SL (1993) Effect of garlic on total serum cholesterol. A meta-analysis. Ann Intern Med 119: 599-605.

12. Amagase $\mathrm{H}$, Petesch $\mathrm{BL}$, Matsuura $\mathrm{H}$, Kasuga $\mathrm{S}$, Itakura $\mathrm{Y}(2001)$ Intake of garlic and its bioactive components. J Nutr 131: 955S-62S

13. Freeman F, Kodera Y (1995) Garlic chemistry: stability of S-(2-propenyl)-2 propene-1-sulfinothiate (allicin) in blood, solvents and simulated physiological fluids. J Agri Food Chem 43: 2332-2338.

14. Lawson LD, Wang ZJ (2001) Low allicin release from garlic supplements: a major problem due to the sensitivities of alliinase activity. J Agric Food Chem 49: 2592-2599.

15. Steiner M, Lin R (1994) Cardiovascular and lipid changes in response to aged garlic extract ingestion. J American Col Nutri 13: 524

16. Amagase $\mathrm{H} 1$ (2006) Clarifying the real bioactive constituents of garlic. J Nutr 136: $716 \mathrm{~S}-725 \mathrm{~S}$

17. Sharma A, Mathur R, Dixit VP (1995) Hypocholesterolemic activity of nut shell extract of Semecarpus anacardium (Bhilawa) in cholesterol fed rabbits. Indian J Exp Biol 33: 444-448

18. Dhanapakiam P, Joseph JM, Ramaswamy VK, Moorthi M, Kumar AS (2008) The cholesterol lowering property of coriander seeds (Coriandrum sativum): mechanism of action. J Environ Biol 29: 53-56.

19. Satyavati GV (1988) Gum guggulu (Commiphora mukul)-The success story of an ancient insight leading to a modern discovery. Indian Journal of Medical Research 87: 327-335.

20. Satyavati GV (1966) Effect of indigenous drug on disorders of lipid metabolism with special reference to atherosclerosis and obesity (Medoroga), M.D. thesis (Doctor of Ayurvedic Medicine), Banaras Hindu University, Varanasi, India.

21. Urizar NL, Moore DD (2003) GUGULIPID: a natural cholesterol-lowering agent Annu Rev Nutr 23: 303-313.

22. Shields KM, Moranville MP (2005) Guggul for hypercholesterolemia. Am J Health Syst Pharm 62: 1012-1014.

23. Szapary PO, Wolfe ML, Bloedon LT, Cucchiara AJ, DerMarderosian AH, et al. (2003) Guggulipid for the treatment of hypercholesterolemia: a randomized controlled trial. JAMA 290: 765-772.

24. Singh RB, Niaz MA, Ghosh S (1994) Hypolipidemic and antioxidant effects of Commiphora mukul as an adjunct to dietary therapy in patients with hypercholesterolemia. Cardiovascular Drugs and Therapy 8: 659-664.

25. Kapoor LD (1990) Handbook of Ayurvedic Medicinal Plants. Boca Raton, FL. CRC Press 319-320.

26. Ram A, Lauria P, Gupta R, Kumar P, Sharma VN (1997) Hypocholesterolaemic effects of Terminalia arjuna tree bark. J Ethnopharmacol 55: 165-169.

27. Gupta R, Singhal S, Goyle A, Sharma VN (2001) Antioxidant and hypocholesterolaemic effects of Terminalia arjuna tree-bark powder: a randomised placebo-controlled trial. J Assoc Physicians India 49: 231-235.

28. Gauthaman K, Maulik M, Kumari R, Manchanda SC, Dinda AK, et al. (2001) 
Citation: Saravanan M, Ignacimuthu S (2015) Hypocholesterolemic Effect of Indian Medicinal Plants - A Review. Med chem 5: 040-049. doi:10.4172/2161-0444.1000241

Effect of chronic treatment with bark of Terminalia arjuna: a study on the isolated ischemic-reperfused rat heart. J Ethnopharmacol 75: 197-201.

29. Warrier PK, Nambiar VPK, Ramankutty C (1995) Indian medicinal plants. Orient Longman Ltd. Chennai, India.

30. Antony B, Merina B, Sheeba V, Mukkadan J (2006) Effect of standardized Amla extract on atherosclerosis and dyslipidemia. Indian Journal of Pharmaceutical Sciences 68: 437-441.

31. Khanna AK, Rizvi F, Chander R (2002) Lipid lowering activity of Phyllanthus niruri in hyperlipemic rats. J Ethnopharmacol 82: 19-22.

32. Thomas A, Soni GL, Singh R (1987) Role of dietary fibre from bengal gram (Cicer arietinum) as hypocholesterolemic agent-effect on erythrocyte membrane-bound enzymes and hematological parameters. Food Science Nutrition, 41F 193-201.

33. Chang MLW, Johnson MA (1977) Influence of dietary fibre (from soybean flour) on lipid metabolism in rats. Nutrition Reports International 16: 573.

34. Helendoorn EW (1979) Beneficial physiological activity of leguminous seeds. Qualitas Plantarum 29: 227.

35. Sharma RD (1980) Effect of hydroxy acids on hypercholesterolaemia in rats. Atherosclerosis 37: 463-468.

36. Singh R, George M, Soni GL (1983) Role of dietary fibre from pulses as hypocholesterolemic agent. J Food Sci Tech 20: 228-230.

37. Menon PV, Kurup PA (1976) Dietary fibre and cholesterol metabolism: effect of fibre rich polysaccharide from blackgram (Phaseolus mungo) on cholestero metabolism in rats fed normal and atherogenic diet. Biomedicine 24: 248-253.

38. Sharma RD (1979) Isoflavones and hypercholesterolemia in rats. Lipids 14 535-539.

39. Warrier PK, Nambiar VPK, Ramankutty C (1994) Indian medicinal plants. Vol.2. Orient Longman Ltd. Chennai, India.

40. Joshi LD, Singhal PC, Gupta RK (1982) Changes in serum cholesterol and blood sugar levels on feeding with Cyamopsis tetragonoloba (guar) and its solvent extracts. Current Science 5: 1037-1039.

41. Sarathy R, Saraswathi G (1983) Effect of tender cluster bean pods (Cyamopsis tetragonoloba) on cholesterol levels in rats. Am J Clin Nutr 38: 295-299.

42. Kawatra A, Kapoor AC, Seghal S (1991) Hypocholesterolemic effect of guargum in overweight adults. Plant Foods Hum Nutr 41: 241-245.

43. Rastogi RP (1995) Compendium of Indian medicinal plants. Publications and Information Directorate, CDRI, New Delhi, India.

44. Uberoi SK, Vadhera S, Soni GL (1992) Role of dietary fibre from pulses and cereals as hypocholesterolemic and hypolipidemic agent. J Food Sci Tech 29: 281-283.

45. Carroll KK (1991) Review of clinical studies on cholesterol-lowering response to soy protein. J Am Diet Assoc 91: 820-827.

46. Potter SM (1995) Overview of proposed mechanisms for the hypocholesterolemic effect of soy. J Nutr 125: 606S-611S.

47. Visavadiya NP, Narasimhacharya AV (2006) Hypocholesterolaemic and antioxidant effects of Glycyrrhiza glabra (Linn) in rats. Mol Nutr Food Res 50 1080-1086.

48. Visavadiya NP, Narasimhacharya AV (2011) Ameliorative effects of herba combinations in hyperlipidemia. Oxid Med Cell Longev 2011: 160408.

49. Sharma RD (1984b) Hypocholesterolemic activity of fenugreek (T. Foenum graecum). An experimental study in rats. Nutrition Reports International 30 221-231.

50. Reddy RL, Srinivasan K (2009) Fenugreek seeds reduce atherogenic dietinduced cholesterol gallstone formation in experimental mice. Can J Physio Pharmacol 87: 933-943.

51. The Wealth of India (1976) (Raw materials) Publications and Information Directorate, Council of Scientific \& Industrial Research, New Delhi, India.

52. Mayilvaganan M, Singh SP, Johari RP (2004) Hypocholesterolemic effect of protein prepared from Phaseolus aconitifolius (Jacq.). Indian J Exp Biol 42 904-908.

53. Thomas M, Leelamma S, Kurup PA (1983) Effect of black gram fibre (Phaseolus mungo) on hepatic hydroxymethylglutaryl-CoA reductase activity, cholesterogenesis and cholesterol degradation in rats. J Nutri 113: 1104-1108.
54. Solanki YB, Jain SM (2010) Antihyperlipidemic activity of Clitoria ternatea and Vigna mungo in rats. Pharm Biol 48: 915-923.

55. Warrier PK, Nambiar VPK, Ramankutty C (1996) Indian medicinal plants. Vol.5. Orient Longman Ltd. Chennai, India.

56. Mahadevappa VG, Raina PL (1983) Hypocholesterolemic effect of cowpea in rats on atherogenic diet. Indian J Med Res 78: 819-823.

57. Gupta S, Mediratta PK, Singh S, Sharma KK, Shukla R (2006) Antidiabetic antihypercholesterolaemic and antioxidant effect of Ocimum sanctum (Linn) seed oil. Indian J Exp Biol 44: 300-304.

58. Geetha RK, Vasudevan DM (2004) Inhibition of lipid peroxidation by botanical extracts of Ocimum sanctum: in vivo and in vitro studies. Life Sci 76: 21-28.

59. Prasad K (2000) Antioxidant activity of secoisolariciresinol diglucoside-derived metabolites, secoisolariciresinol, enterodiol, and enterolactone. International Journal of Angiology 9: 220-225.

60. Kitts DD, Yuan YV, Wijewickreme AN, Thompson LU (1999) Antioxidant activity of the flaxseed lignin secoisolariciresinol diglycoside and its mammalian lignin metabolites enterodiol and enterolactone. Molecular and Cellular Biochemistry 202: $91-100$.

61. Vijaimohan K, Jainu M, Sabitha KE, Subramaniyam S, Anandhan C, et al. (2006) Beneficial effects of alpha linolenic acid rich flaxseed oil on growth performance and hepatic cholesterol metabolism in high fat diet fed rats. Life Sci 79: 448-454.

62. Ghasi S, Nwobodo E, Ofili JO (2000) Hypocholesterolemic effects of crude extract of leaf of Moringa oleifera Lam in high-fat diet fed wistar rats. J Ethnopharmacol 69: 21-25.

63. Mehta K, Balaraman R, Amin AH, Bafna PA, Gulati OD (2003) Effect of fruits of Moringa oleifera on the lipid profile of normal and hypercholesterolaemic rabbits. J Ethnopharmacol 86: 191-195.

64. Rajamohan T, Kurup PA (1997) Lysine: Arginine ratio of a protein influences cholesterol metabolism part-1 studies on sesame protein having low lysine: arginine ratio. Indian Journal of Experimental Biology 35: 1218-1223.

65. Visavadiya NP, Narasimhacharya AV (2008) Sesame as a hypocholesteraemic and antioxidant dietary component. Food Chem Toxicol 46: 1889-1895.

66. The Wealth of India (1966) (Raw materials) Publications and Information Directorate, Council of Scientific \& Industrial Research, New Delhi, India. 3 $\mathrm{N}-\mathrm{Pe}$.

67. Rukmini C, Raghuram TC (1991) Nutritional and biochemical aspects of the hypolipidemic action of rice bran oil: a review. J Am Coll Nutr 10: 593-601.

68. Sugano M, Tsuji E (1997) Rice bran oil and cholesterol metabolism. J Nutr 127 521S-524S.

69. Kerckhoffs DA, Brouns F, Hornstra G, Mensink RP (2002) Effects on the human serum lipoprotein profile of beta-glucan, soy protein and isoflavones, plant sterols and stanols, garlic and tocotrienols. J Nutr 132: 2494-2505.

70. Most MM, Tulley R, Morales S, Lefevre M (2005) Rice bran oil, not fiber, lowers cholesterol in humans. Am J Clin Nutr 81: 64-68.

71. Sharma RD, Rukmini C (1987) Hypocholesterolemic activity of unsaponifiable matter of rice bran oil. Indian J Med Res 85: 278-281.

72. Gupta RS, Dixit VP, Dobhal MP (2002) Hypocholesterolaemic effect of the oleoresin of Capsicum annum L. in gerbils (Meriones hurrianae Jerdon) Phytother Res 16: 273-275.

73. Sambaiah K, Satyanarayana MN (1980) Hypocholesterolemic effect of red pepper \& capsaicin. Indian J Exp Biol 18: 898-899.

74. Mishra LC, Singh BB, Dagenais S (2000) Scientific basis for the therapeutic use of Withania somnifera (ashwagandha): a review. Altern Med Rev 5: 334-346.

75. Andallu B, Radhika B (2000) Hypoglycemic, diuretic and hypocholesterolemic effect of winter cherry (Withania somnifera, Dunal) root. Indian J Exp Biol 38 607-609.

76. Visavadiya NP, Narasimhacharya AV (2007) Hypocholesteremic and antioxidant effects of Withania somnifera (Dunal) in hypercholesteremic rats. Phytomedicine 14: 136-142.

77. Mukherjee PK1 (2003) Plant products with hypocholesterolemic potentials. Adv Food Nutr Res 47: 277-338.

78. Cooper RA (1977) Abnormalities of cell-membrane fluidity in the pathogenesis of disease. N Engl J Med 297: 371-377. 
Citation: Saravanan M, Ignacimuthu S (2015) Hypocholesterolemic Effect of Indian Medicinal Plants - A Review. Med chem 5: 040-049. doi:10.4172/2161-0444.1000241

79. Kempaiah RK, Srinivasan K (2005) Influence of dietary spices on the fluidity of erythrocytes in hypercholesterolaemic rats. $\mathrm{Br} \mathrm{J}$ Nutr 93: 81-91.

80. Peschel D, Koerting R, Nass N (2007) Curcumin induces changes in expression of genes involved in cholesterol homeostasis. J Nutr Biochem 18: 113-119.

81. Whayne TF, Alaupovic PS, Curry MD, Lee ET, Anderson PS, et al. (1981) Plasma apolipoprotein B and VLDL-, LDL-, and HDL-cholesterol as risk factors in the development of coronary artery disease in male patients examined by angiography. Atherosclerosis 39: 411-424.

82. Goldstein JL, Brown MS (1977) The low-density lipoprotein pathway and its relation to atherosclerosis. Annu Rev Biochem 46: 897-930.

83. Jenkins PJ, Harper RW, Nestel PJ (1978) Severity of coronary atherosclerosis related to lipoprotein concentration. $\mathrm{Br}$ Med J 2: 388-391.

84. Schlant RC, Wayne R (1994) Hurst's The Heart- Arteries and Veins, 8th ed. Mc.Graw-Hill Inc, New York.

85. Srinivasan K, Sambaiah K, Chandrasekhara N (2004) Spices as beneficial hypolipidemic food adjuncts: a review. Food Reviews International 20: 187220.

86. Gustafsson BE, Angelin B, Einarsson K, Gustafsson JA (1978) Influence of cholestyramine on synthesis of cholesterol and bile acids in germfree rats. $\mathrm{J}$ Lipid Res 19: 972-977.

87. Venkatesan N, Devaraj SN, Devaraj H (2003) Increased binding of LDL and VLDL to apo $B, E$ receptors of hepatic plasma membrane of rats treated with Fibernat. Eur J Nutr 42: 262-271.

88. Ostlund RE Jr1 (2004) Phytosterols and cholesterol metabolism. Curr Opin Lipidol 15: 37-41.

89. Francis G, Kerem Z, Makkar HP, Becker K (2002) The biological action of saponins in animal systems: a review. Br J Nutr 88: 587-605.

90. Antony B, Merina B, Sheeba $V$ (2008) Amlamax in the management of dyslipidemia in humans. Indian J Pharm Sci 70: 504-507.

91. Augusti KT (1977) Hypocholesterolaemic effect of garlic, Allium sativum Linn. Indian J Exp Biol 15: 489-490

92. Babu PS, Srinivasan K (1997) Hypolipidemic action of curcumin, the active principle of turmeric (Curcuma longa) in streptozotocin induced diabetic rats. Mol Cell Biochem 166: 169-175.

93. Boban PT, Nambisan B, Sudhakaran PR (2009) Dietary mucilage promotes regression of atheromatous lesions in hypercholesterolemic rabbits. Phytother Res 23: 725-730.

94. Das SN, Pramanik AK, Mitra SK, Mukherjee BN (1982) Effect of garlic pearls (Ranbaxy) on blood cholesterol level in normal dogs. Indian veterinary Journal 59: 937-938.

95. Dhawan V, Jain S (2004) Effect of garlic supplementation on oxidized low density lipoproteins and lipid peroxidation in patients of essential hypertension. Mol Cell Biochem 266: 109-115.

96. Gadkari JV, Joshi VD (1991) Effect of ingestion of raw garlic on serum cholesterol level, clotting time and fibrinolytic activity in normal subjects. J Postgrad Med 37: 128-131.

97. Godkar PB, Narayanan P, Bhide SV (1996) Hypocholesterolemic effect of turmeric extract on Swiss mice. Indian Journal of Pharmacology 28: 171-174.

98. Gopalan R, Gracias D, Madhavan M (1991) Serum lipid and lipoprotein fractions in bengal gram and biochanin $A$ induced alterations in atherosclerosis. Indian Heart J 43: 185-189.

99. Gupta PP, Khetrapal P, Ghai CL (1987) Effect of garlic on serum cholesterol and electrocardiogram of rabbit consuming normal diet. Indian J Med Sci 41: $6-11$.

100. Hemalatha S, Wahi AK, Singh PN, Chansouria JP (2006) Hypolipidemic activity of aqueous extract of Withania coagulans Dunal in albino rats. Phytother Res 20: 614-617.

101. Jacob A, Pandey M, Kapoor S, Saroja R (1988) Effect of the Indian gooseberry (amla) on serum cholesterol levels in men aged 35-55 years. Eur J Clin Nutr 42: 939-944.

102.Jain RC, Konar DB (1978) Effect of garlic oil in experimental cholesterol atherosclerosis. Atherosclerosis 29: 125-129.

103. Jayakumari N, Nampoothiri VK, Nambisan B, Kurup PA (1978) Lowering of aortic cholesterol in hypercholesterolemic rats: effect of vitamin A, Ascorbic acid, protein fraction from blackgram, bovine aortic \& intestinal mucosal MPS \& zinc salts. Indian J Exp Biol 16: 1289-1291.

104. Jayakumari N, Kurup PA (1979) Dietary fiber and cholesterol metabolism in rats fed a high cholesterol diet. Atherosclerosis 33: 41-47.

105. Jeyaraj S, Shivaji G, Jeyaraj SD, Vengatesan A (2005) Effect of combined supplementation of fish oil with garlic pearls on the serum lipid profile in hypercholesterolemic subjects. Indian Heart J 57: 327-331.

106. Kamanna VS, Chandrasekhara N (1982) Effect of garlic (Allium sativum linn) on serum lipoproteins and lipoprotein cholesterol levels in albino rats rendered hypercholesteremic by feeding cholesterol. Lipids 17: 483-488.

107.Kaul PL, Prasad MC (1990) Hypocholesterolemic and antiatherosclerotic effects of garlic (Allium sativum L) in goats-An experimental study. Indian Veterinary Journal 67: 1112-1115.

108. Kempaiah RK, Srinivasan K (2002) Integrity of erythrocytes of hypercholesterolemic rats during spices treatment. Mol Cell Biochem 236: 155-161.

109. Kempaiah RK, Manjunatha H, Srinivasan K (2005) Protective effect of dietary capsaicin on induced oxidation of low-density lipoprotein in rats. Mol Cell Biochem 275: 7-13.

110. Khanna DS, Agarwal OP, Gupta SK, Arora RB (1969) A biochemical approach to anti-atherosclerotic action of Commiphora-mukul: an Indian indigenous drug in Indian domestic pigs (Sus scrofa). Indian J Med Res 57: 900-906.

111. Kuppurajan K, Rajagopalan SS, Rao TK, Sitaraman R (1978) Effect of guggulu (Commiphora mukul--Engl.) on serum lipids in obese, hypercholesterolemic and hyperlipemic cases. J Assoc Physicians India 26: 367-373.

112. Malhotra CL, Agarwal YK, Mehta VL, Prasad S (1970) The effect of various fractions of gum guggul on experimentally produced hypercholesteraemia in chicks. Indian J Med Res 58: 394-395.

113. Mand JK, Soni GL, Gupta PP, Vadhera S, Singh R (1991) Role of Benga gram (Cicer arietinum) seed coat as an antiatherogenic agent in rabbits. Indian Heart J 43: 347-350.

114. Manjunatha $\mathrm{H}$, Srinivasan K (2007) Hypolipidemic and antioxidant effects of dietary curcumin and capsaicin in induced hypercholesterolemic rats. Lipids 42: $1133-1142$.

115. Mathur KS, Sharma RD, Singhal SS (1964a) Hypocholesterolemic action of bengal gram (Cicer arietinum), experimental study in albino rats and human volunteers. Cardiology 3rd (Kyoto) 579-588.

116. Mathur KS, Singhal SS, Sharma RD (1964) Effect of bengal gram on experimentally induced high levels of cholesterol in tissues and serum in albino rats. J Nutr 84: 201-204.

117. Mirhadi SA, Singh S, Gupta PP (1991) Effect of garlic supplementation to cholesterol-rich diet on development of atherosclerosis in rabbits. Indian J Exp Biol 29: 162-168.

118. Nityanand S, Kapoor NK (1971) Hypocholesterolemic effect of Commiphora mukul resin (guggal). Indian J Exp Biol 9: 376-377.

119. Nityanand S, Kapoor NK (1973) Cholesterol lowering activity of the various fractions of the guggal. Indian J Exp Biol 11: 395-396.

120. Nityanand S, Srivastava JS, Asthana OP (1989) Clinical trials with gugulipid. A new hypolipidaemic agent. J Assoc Physicians India 37: 323-328.

121. Rai SK, Sharma M, Tiwari M (2009) Inhibitory effect of novel diallyldisulfide analogs on HMG-CoA reductase expression in hypercholesterolemic rats: CREB as a potential upstream target. Life Sci 85: 211-219.

122. Rajasree CR, Rajmohan T, Augusti KT (2009) Antiatherogenic and antiperoxidative effects of garlic and soy proteins in alcohol fed rats. Indian J Exp Biol 47: 169-175.

123. Satyavati GV, Dwarakanath C, Tripathi SN (1969) Experimental studies on the hypocholesterolemic effect of Commiphora mukul. Engl. (Guggul). Indian J Med Res 57: 1950-1962.

124. Sharma KK, Chowdhury NK, Sharma AL (1975a) Long term effect of onion on experimentally induced hypercholesterolemia and consequently decreased fibrinolytic activity in rabbits. Indian Journal of Medical Research 63: 16291634

125. Sharma KK, Chowdhury NK, Sharma AL (1975b) Studies on hypocholesteremic activity of onion. II. Effect on serum cholesterol in rabbits maintained on high cholesterol diet. Indian Journal of Nutrition and Dietetics 12: 388-391. 
Citation: Saravanan M, Ignacimuthu S (2015) Hypocholesterolemic Effect of Indian Medicinal Plants - A Review. Med chem 5: 040-049. doi:10.4172/2161-0444.1000241

126. Sharma KK, Sharma AL, Dwivedi KK, Sharma PK (1976) Effect of raw and boiled garlic on blood cholesterol in butter fat lipaemia. Indian Journal of Nutrition and Dietetics 13:7-10.

127. Sharma RD (1984a) Hypocholesterolemic effect of hydroxy acid components of bengal gram. Nutrition Reports International 29: 1315-1322.

128. Singh M, Kanakaraj $P$ (1985) Hypocholesterolemic effect of onion extract on cholesterol-enriched erythrocytes. Indian J Exp Biol 23: 456-459.

129. Soni GL, George M, Singh R (1982) Role of common Indian pulses as hypocholesterolemic agents. Indian Journal of Nutrition and Dietetics 19: 184-190.

130. Soudamini KK, Unnikrishnan MC, Soni KB, Kuttan R (1992) Inhibition of lipid peroxidation and cholesterol levels in mice by curcumin. Indian $\mathrm{J}$ Physiol Pharmacol 36: 239-243.

131.Rao DS, Sekhara NC, Satyanarayana MN, Srinivasan M (1970) Effect of curcumin on serum and liver cholesterol levels in the rat. J Nutr 100: 13071315.

132. Babu PS, Srinivasan K (1995) Influence of dietary curcumin and cholesterol on the progression of experimentally induced diabetes in albino rat. Mol Cell Biochem 152: 13-21.

133. Thakur CP, Ali M (1982) Egg protein and defatted soya protein on cholesterol induced hypercholesterolaemia and atherosclerosis in rabbits. Indian $\mathrm{J}$ Med Res 75: 862-867.

134. Thakur CP (1985) Emblica officinalis reduces serum, aortic and hepatic cholesterol in rabbits. Experientia 41: 423-424.

135. The Wealth of India (1985) (Raw materials) Publications and Information Directorate, Council of Scientific \& Industrial Research, New Delhi, India 1 : 530-554.

136. Thomas M, Leelamma S, Kurup PA (1986) Effect of dietary protein on cholesterol lowering action of blackgram fiber. Indian J Biochem Biophys 23 : 179-181.

137.Vadhera S, Punia KA, Soni GL (1995) Hypocholesterolemic/Hypolipidemic effect of dietary fibres from outer skin of garlic and onion L. Food Science and Technology 32: 62-64.

138. Vatsala TM, Singh M (1980) Effects of hypercholesterolemia and onions on rheology of blood in rabbits. Biorheology 17: 261-266.

139. Vatsala TM, Singh M (1981) Relationship between plasma cholesterol level and erythrocytes shape in rabbits on atherogenic diet and onion extracts. Current Science 50: 211-213.

140. Bhushan S, Sharma SP, Singh SP, Agrawal S, Indrayan A, et al. (1979) Effect of garlic on normal blood cholesterol level. Indian J Physiol Pharmacol 23: 211-214. 